\title{
A INDÚSTRIA DA BELEZA E A SUSTENTABILIDADE
}

Dentre as diversas variáveis que afetam o ambiente de negócios, a preocupação com a beleza e o bem-estar e, ao mesmo tempo, com o meio ambiente, ganhou destaque significativo por afetar a imagem corporativa e seus resultados econômicos. De acordo com a organização mundial de saúde, Saúde é um estado de completo bem-estar físico, mental e social e não apenas a ausência de doenças ou enfermidades, por isso a preocupação com a beleza através do uso de cosméticos e de roupas de estilo, ditadas pela indústria da moda, ajudam as pessoas a se sentirem saudáveis.

Porém esta indústria que movimenta uma parcela significativa da economia, só a indústria da moda teve um faturamento é de 35.000 bilhões de dólares em 2020 e a de cosmético 130 bilhões de dólares em 2020, tem estado na pauta de organizações internacionais devido as ameaças ao meio ambiente, pois suas ações tem dificultado o alcance das metas do milênio estabelecidas pela agenda da ONU 2030.

A indústria da moda destaca-se como um dos maiores fornecedores de produtos e empregos nos países em desenvolvimento, principalmente devido à ocorrência do modelo de produção Fast Fashion. Porém os malefícios para o meio ambiente dessa indústria vão desde o uso de pesticidas no plantio de algodão (25\% de todos os pesticidas utilizados mundialmente vão para o algodão), passando pelo processo produtivo de têxteis que utiliza uma grande quantidade de substâncias como naftol, enxofre, enzimas, sabão, corantes, e desinfetantes como cloro durante a confecção das roupas, resultando em compostos cancerígenos. Chegando ao final da cadeia produtiva cerca de $32 \mathrm{~kg}$ de materiais têxteis por pessoa atualmente rejeitados em todo o mundo a cada ano, totalizando $85 \%$ do volume total disposto em aterros sanitários ou incinerados, contribuindo para o aumento dos impactos ambientais como o uso excessivo de água, energia, produtos químicos e destinação inadequada de resíduos.

A indústria de cosmético não é diferente, os principais produtos de higiene e cuidados pessoais, como xampus, bloqueador de UV-A, desodorantes, cremes, limpadores faciais, makeoffs e dentifrícios, podem apresentar metais pesados em sua composição, por exemplo, o chumbo, cromo, níquel, alumínio, cobre e cádmio. Além disso, as formulações contêm ácidos graxos, surfactantes, derivados de petróleo e detergentes. Portanto, parte dessas composições gera subprodutos industriais junto com águas residuais e são caracterizadas por valores de demanda química de oxigênio relativamente altos (> $100.000 \mathrm{mgL}^{-1}$ ), que se não receberem tratamento adequado, podem causar danos irreversíveis ao meio ambiente.

A sustentabilidade aliada a indústria da beleza exige mudanças nas diretrizes de mercado que vislumbre a sustentabilidade e a economia circular como uma nova possibilidade de crescimento e responsabilidade ambiental e social, sem excluir a possibilidade de incentivos às práticas ambientais por parte do governo e de instituições privadas.

Nessa nova perspectiva, as empresas estão gradativamente mudando sua postura em relação aos aspectos ambientais, pois é necessário continuar produzindo cosméticos e têxteis, porém em um processo de conciliação entre a produção e os cuidados com o meio 
ambiente, visando o desenvolvimento sustentável. Desde então, alguns procedimentos foram revisados, buscando alternativas para evitar e reduzir a geração de resíduos e melhorar seus ganhos socioeconômicos

$\mathrm{Na}$ indústria cosmética uma fatia $(2,5 \%)$ é formada por produtos naturais: cosméticos sem reagentes químicos, com cadeia sustentável de fornecedores, sem testes em animais e, em alguns casos, até vegana. Esses produtos naturais, menos agressivos ao meio ambiente, estão ganhando espaço nas prateleiras - tanto das feirinhas de rua quanto das farmácias e mercados. Segundo a BioBrazil Fair, maior feira de produtos orgânicos e naturais da América Latina, mercado de cosméticos naturais cresce em ritmo acelerado, e sozinho já movimenta anualmente cerca de $\mathrm{R} \$ 3$ bilhões.

$\mathrm{Na}$ indústria têxtil, a economia circular tem sido o foco principal tanto para reaproveitamento de resíduos têxteis para outros segmentos como da construção civil como uso de resíduos de outras industrias como matéria prima para novos têxteis, exemplo do uso de resíduos da indústria de alimentos para fabricação de têxteis biodegradáveis.

A aliança entre os setores da beleza e a sustentabilidade se utiliza de tecnologias limpas como a química verde em cosméticos e também em têxteis, utilizando novos materiais biodegradáveis de fontes renováveis e com menor consumo de água da produção ao consumo. A economia circular também é um assunto importante a ser discutido nas indústrias cosmética e têxtil, lembrando que os resíduos de uma empresa devem ser aproveitados como matéria-prima de outra.

Além disso, enfatiza-se práticas de desenvolvimento sustentável precisam ser aplicadas não apenas com o objetivo de proporcionar um novo mercado verde para as indústrias, mas também ser priorizadas em prol do meio ambiente, a fim de minimizar impactos ambientais de forma eficaz, tanto social como econômico e ambiental.

\section{Referências}

PROVIN, A.P., DUTRA, A.R.A, MACHADO,M.M, CUBAS, A.L.V. New materials for clothing: Rethinking possibilities through a sustainability approach - A review,Journal of Cleaner Production,Volume 282, 2021, 124444, ISSN 0959-6526, https://doi.org/10.1016/j.jclepro.2020.124444.

BIANCHET, R.T., CUBAS, A.L.V., MACHADO, M.M., MOECKE, E.H.S.

Applicability of bacterial cellulose in cosmetics - bibliometric review, Biotechnology

Reports, Volume 27, 2020, https://doi.org/10.1016/j.btre.2020.e00502.

\section{Anelise Leal Vieira Cubas, Dr}

Programa de Pós-Graduação em Ciências Ambientais

Universidade do Sul de Santa Catarina (UNISUL) 